\title{
EDITORIAL
}

\section{To the mystery of cell biology}

\author{
Karel Smetana \\ Institute of Hematology and Blood Transfusion, Prague, Czech Republic
}

When you are old enough and and have been,like me, involved in the field of cell biology for a long time, you are frequently asked for comment on many related topics. At first, I used to object to talking about the mystery of cell biology but then I changed my mind. As a consequence, you are now forced to listen to my thoughts on the subject. My ideas of course are not new and I am sure that everyone in the field shares them with me.

Cell biology is a mystery for many reasons one of which is the lack of basic knowledge. This may be the fault of scientists or simply a failure in basic information at the level of common contemporary knowledge. The well known sentence of Socrates: "I know that I know nothing" is as true in cell biology as in other scientific fields. This sentence was modified by Lloyd in 1986 who claimed: "The closer we look, the less we see". I would like to modify this sentence yet again as a cell biologist and microscopist: "The closer we look, the less we know about". All these postulates are true because the cell represents a very complicated system which is influenced by the environment in which the cell is actually living. Moreover, every period of scientific development starting with the $19^{\text {th }}$ century. is considered to be equally successful in contributing to knowledge in this field.

Newly presented discoveries may frequently be re-discoveries, are rarely new nor provide new areas important for research. The rediscoveries are not useless since they confirm what was discovered before. On the other hand, everyone involved in cell biology, is surprised how limited is our knowledge about the various cell compartments. Such recognition is very useful and stimulating because we all love to contribute to present knowledge with new observations and we are all full of curiosity - a necessary motivator in the discovery of new and original data as well as ideas for future research.
The great strength of contemporary research in cell biology is the number of joint efforts and cooperation between various scientific disciplines. Past antagonisms between the various methodological approaches are being replaced by cooperation. Such a development in cell biology was predicted at the Vesalius symposium on the future of biomedical sciences in Belgium (1964) mainly in the general discussion sessions at this meeting (Brachet). It seemed clear to all of us that newly published original observations are asking new questions, suggesting that as in all science, research on the cell is endless. It should now be mentioned that our knowledge even of basic cell organelles, including their various functions, is very limited. They are still mysterious and their abnormality results in pathological states not only of the cell but usually of the whole organism. Applied biological sciences such as human, veterinary and plant medicine as well as agronomy and other scientific fields fully depend on basic knowledge of the cell and various cell types (including the specialized). It should be added that our influence over cell behavior may be useful for mankind or just very dangerous. We have to consider that research dangerous for mankind will still proceed in some laboratories but its consequences must be minimized.

It is very difficult to say what in numerous areas of the cell research is or will be important or not important. Past years have frequently indicated that so called "important" topics and directions were faulty and so called "unimportant" ones represented leading directions for research. I have seen it again just recently at several conferences. Remember how many research programmes were devoted to cell proliferation and how cell death was neglected until recent years. Research on the programmed cell death provided extremely important results which are very 
useful in applied biomedical sciences such as clinical medicine and oncology (e.g. see Plunkett 1995). It seems clear that the therapeutical approach to malignancy in the future will be different depending on whether the growing mass of malignant cells is produced by increased cell proliferation or just by longer cell survival. I feel strongly about the fact that research on the nucleolus was neglected for so many years despite its importance in diagnostic cytology. Even now, we know only some of the nucleolar functions related to the nucleolar structure (e.g. see Pederson 1998). We know something about cell organelles, including various nuclear compartments, but most of their functions are waiting for further and better clarification. Take the case of mitochondria; until the past few years we did not know anything about their participation in the apoptotic process.

It should also be remembered how the cell transformations already known in the first part of the last century were underestimated. It does not now surprise us that the pluripotent mesenchymal cell of the bone marrow may differentiate not only to hematopoietic cells but also to fibroblasts, osteoblasts, chondroblasts, adipocytes, or even to kardiomyocytes (see e.g. Hirschi and Goodell 2002, Wang et al. 2001). Such transformations are clinically important and the first results are very optimistic. For the histologist or embryologist such transformations under defined conditions seem to be natural since most of these cells are of mesenchymal origin. However, mesenchymal stem cells of the bone marrow also transform to completely different cell types of different origin such as neuroblasts, hepatocytes, skin as well as intestine epithelial cells or mesangial cells during glomerular remodeling in the kidney (Hirschi and Goodell 2002, Ito et al. 2001, Körbling et al. 2002, Zhao et al. 2002). From the general point of view all these transformations are just a consequence of a generally known fact that all cells carry the whole genome. Depending on conditions, selected genes may be repressed or derepressed and activated giving to rise to the particular cell lineage with characteristic cell structures and functions. On the other hand, such transformations, including the homing of the transformed cells are also very mysterious although both these processes are empirically used in clinical medicine. It is more than interesting how the transformed cell knows where it must home (nidate), proliferate, futher differentiate, and be functionally active. Such questions are opening new and very large areas for basic research on involved internal as well external cell compartments.

It is useless to speak about particular fields of cell biology because everyone who is involved knows their weak or strong topics and frequently must resist the fact that their research is not well understood and remains without grant support. However, it is mostly profitable for him to follow development which is at least in some small areas disclosing the mystery of various cell compartments. It should now be mentioned how important are methodical approaches and developments. The first steps were represented by the morphological methods which were gradually replaced by functional and biochemical approaches at different levels and finally at macromolecular and molecular ones. At present, all approaches should be considered as complementary since each methodical approach must not be over- or underestimated. All methodical approaches are continuously improved and the price of instruments as well as chemicals is increasing and one must admit that cell biology research is accompanied by great industrial development. In addition, the role of computors in obtaining better information as well as evaluation of achieved results is also continuously increasing. Summarizing these developments one must agree with the conclusion of cell biologists in the first part of the last century who claimed that the methodical approach is determining the success of our observations. In addition, it seems to be clear how the planning and evaluation of the selected methodical approach are important. There may be unfortunate overextensions and misinterpretations when the students of the cell are unfamiliar with limitations of various procedures (Busch 1967).

It should be also mentioned that the generalization and insertion of achieved results into present knowledge is as important as the research itself. It has been shown many times that the compendium of various reports resulting in a good review may discover facts and relationships which were not mentioned in the original publications. The compendia dealing with cell biology topics may be a base for other sciences including the social sciences and philosophy. They may influence these sciences not only positively but also negatively. There are numerous examples in history. Remember cell theory, genetics, theories of hierarchic systems and levels of organization in biology (e.g. see De Robertis et al. 1970). I would like to recall not only the hierarchy outside the cell, organism i.e. in society but also within and around the cell. Particularly for cell biology the later topics are very mysterious and should be studied more intensely than in the past. Since these notes were first presented at the symposium Cells IV, it has been demonstrated that a "master molecule" may control hundreds of different genes through its action on enzymes (Steger et al. 2002). 


\section{CONCLUSION}

In conclusion I would like to say that all topics in cell biology represent a mystery regardless of whether they were or were not studied before we were involved. It depends on circumstances which field we select for our research. The process of cell research is continuous and from the contemporary point of view - endless. It should be also mentioned that cell research and results achieved influence substantially not only the biological sciences but also others including philosophy.

Published online $27^{\text {th }}$ February 2003 .

\section{REFERENCES}

Busch H.: Preface. In H. Busch (ed.): Methods in Cancer Research 1. Academic Press, New York 1967.

De Robertis E.D.P., W.W. Nowinski, F.A. Saez: Cell biology, 5ed. W.B. Saunders, Philadelphia, 1970.

Hirschi K.K. and M.A. Goodell: Hematopoietic, vascular and cardiac fates of bone marrow derived stem cells. Gene Ther. 9: 648-652, 2002.

Ito T., A. Suzuki, E. Imai, M. Okabe, M. Hori: Bone marrow is a reservoir of repopulating mesangial cells during glomerular remodeling. J. Am. Soc. Nephrol. 12: 2625-2635, 2001.
Körbling M., R.L. Katz, A. Khanna, A.C. Ruifrok, G. Rondon, M. Albitar, R.E. Champlin, Z. Estrov: Hepatocytes and epithelial cells of donor origin in recipients of peripheral blood stem cells. N. Engl. J. Med. 346: 738-736, 2002.

Lloyd C.: The closer we look the less we see. TIBS 11: 437, 1986.

Pederson T.: The plurifunctional nucleolus. Nucleic Acid Res. 26: 3871-3876, 1998.

Plunkett W.: Apoptosis. CBC Oxford, Oxford, 1995. Steger D.J., E.S. Haswell, A. Miller, S.R. Wente, E.K. O'Shea: Regulation of chromatin remodeling by inositol phosphatases. Science, published on line November 14, 2002, Bio.com. November 19, 2002.

Wang J.S., D. Shum-Tim, E. Chedrawy, R.C. Chiu: The coronary delivery of marrow stroma cells for myocardial regeneration: pathophysiolgic and therapeutic implications. J. Thorac. Cardiovasc. Surg. 122: 699-105, 2001.

Zhao L.R., W.M. Duan, M. Reyes, C.M. Verfaille, W.C. Low: Human bone marrow stem cell exhibit neural phenotypes and ameliorate neurological deficits after grafting into ischemic brain of rats. Exp. Neurol. 174: 11-20, 2002.

Presented at the opening ceremony to the International Symposium Cells IV, České Budějovice, September 2002.

\section{Address:}

Karel Smetana, Institute of Hematology and Blood Transfusion, 12800 Praha 2, U Nemocnice 1, Czech Republic; Karel.Smetana@uhkt.cz 